\title{
USE OF Aspergillus repens IN THE MOULDING PROCESS OF DRIED FISH STICK MADE FROM LITTLE TUNA (Euthynnus affinis)
}

\author{
Hari Eko Irianto1), Fran Santoso2), Jamal Basmal 1), and Ninoek Indriati ${ }^{1)}$ \\ ') Research Center for Marine and Fishery Product Processing and Biotechnology, Jakarta \\ ${ }^{2)}$ Graduate from the Faculty of Marine Sciences and Fishery, Bogor Agricultural University, Bogor \\ Received April 18-2008; Received in revised form Juny 10-2008; Accepted September 2-2008
}

\begin{abstract}
Dried fish stick is a popular product in Japan and called as Arabushi. The product which has undergone moulding process known as Katsuobushi. So far, Indonesia, particularly North Sulawesi Province, exports dried fish stick to Japan. Dried fish stick used in this study was made from little tuna (Euthynnus affinis) through smoking process. Prior to moulding process, the products were divided into two lots. The first lot was irradiated using ultraviolet rays for sterilization purpose and the second lot was without irradiation treatment. For moulding process, starter culture solution of Aspergillus repens was sprayed over the surface of each dried fish stick lot. The dried fish stick was kept in glass boxes having 85 to $95 \%$ relative humidity level for 4 weeks. The samples were withdrawn every week and analyzed chemically and organoleptically. Chemical analyses included $\mathrm{pH}$, moisture, $\mathrm{a}_{w}$, protein, fat, and phenol contents. Organoleptic acceptability of the dried fish stick extract was evaluated in terms of odour and taste. Results indicated that dried fish stick without irradiation treatment was more acceptable than the product with irradiation. The most acceptable product was the one without irradiation treatment and undergoing 4 weeks moulding process.
\end{abstract}

KEYWORDS: dried fish stick, little tuna, irradiation, Aspergillus repens, moulding

\section{INTRODUCTION}

One of the processing methods which are widely adopted by fish processors in Indonesia is smoking. Smoking is not only for preservation purposes, but also for generating desired taste. Smoking process is based on the reduction of moisture content inducing the product being dry and hard texture. In the processing of dried fish stick, smoking is carried out several times until hard texture achieved and the product called as ikan kayu (ikan: fish; kayu: wood). This type of process is widely applied in Japan and the product called as Arabushi. Dried fish stick produced by Indonesian processors are not for local market, but exported to Japan (Basmal \& Irianto, 2000). North Sulawesi Province is the main exporter of dried fish stick (Arabushi). Fish which are frequently processed into dried fish stick are little tuna (Euthynnus affinis) and skipjack (Katsuwonus pelamis).

Arabushi imported by Japan is then received further process to obtain a desired product. The main further process is moulding using certain mould species to produce Katsuobushi. Moulds expected to grow on dried fish stick during moulding process are Aspergillus glaucus, Penicilium glaucum and Aspergillus melleus (Tanikawa, 1971). Doi et al. (1989) isolated moulds from Katsuobushi, i.e. Aspergillus repens (5 strains), A. glaucus (4 strains) and $A$. candidus (2 strains). A. repens was used in this study. According to a description outlined by Onions et al.
(1981), A. repens is included in the group of $A$ glaucus consisting of $A$. echimulatus, $A$ amstelodami, $A$. repens, $A$. ruber, and $A$. chevalier.

The study was aimed to determine the moulding period of dried fish stick by using $A$. repens as a starter culture and to investigate the effects of irradiation treatment on the product quality.

\section{MATERIALS AND METHODS}

Moulding process in this study was carried out in glass boxes with controlled environment, especially relative humidity level.

\section{Materials}

Raw material used to process dried fish stick in this study was little tuna (Euthynnus affinis) purchased from Pelabuhan Ratu Landing Place, Sukabumi, West Java. The fish was transported to the Research Center for Marine and Fishery Product Processing and Socio Economic, Jakarta by preserving in a cool box using ice. Chemical analyses indicated that little tuna used in this study contained $76.3 \%$ moisture, $21.2 \%$ protein, and $2.1 \%$ fat.

\section{Processing of Dried Fish Stick}

Firstly, little tuna was dressed by removing heads, fins and visceral parts. The fish was then boiled at 80 to $90^{\circ} \mathrm{C}$ for 2 hours. After that, the boiled fish was 
placed on the bamboo trays and blown using a fan to make them cool. The bones were removed manually and the fish were then cut into two pieces. The fish were subsequently put on the smoking trays with the position of flesh part facing down. The trays were transferred into smoking cabinet and the distance between smoking source and the trays was approximately 100 to $150 \mathrm{~cm}$. Smoking process applied was hot smoking at 60 to $80^{\circ} \mathrm{C}$. Smoking was carried out in 5 steps, in which each step was performed for 5 hours. After each smoking step completed, the fish was kept at ambient temperature for a day. Due to smoking conducted at high temperature, cracking on the surface of the loin occurred in the first smoking step. The crack was then mend using fish paste. Smoking was stopped after the completion of the fifth smoking. The product obtained from this smoking process is called as dried fish stick or Arabushi with the properties as follows $14 \%$ moisture content, $0.74 \mathrm{a}_{w}$, goldiest brown surface colour and hard texture in the middle part of the fish flesh.

\section{Moulding Process}

A. repens which were going to be used for starter culture were grown on a sliding CYA media at ambient temperature for 7 days. $5 \mathrm{ml}$ of $0.85 \% \mathrm{NaCl}$ solution was poured into the tubes and shaked to remove the moulds. Starter culture solution was then sprayed over the whole surface of dried fish stick, i.e. $5.5 \mathrm{ml}$ starter culture solution for a piece of dried fish stick. The dried fish stick products which have been treated with mould culture solution were ready to undergo moulding process. Moulding was carried out by placing the dried fish stick in glass boxes. Dimension of the glass box was $25 \mathrm{~cm}$ width, $30 \mathrm{~cm}$ length, and $25 \mathrm{~cm}$ height. The hole was made on the top surface of the box. The hole of the moulding glass box for irradiated dried fish stick was connected using plastic tube into water to avoid direct contact with air outside the box. Recorded inside condition of the box was 85 to $95 \%$ RH and 27 to $29^{\circ} \mathrm{C}$.

\section{Irradiation Process}

Irradiation treatment to dried fish stick prior to moulding process was conducted in the National Agency for Atomic Energy, Jakarta. Firstly, the dried fish stick was packed in polyethylene bags. The fish was then irradiated using 3.8 kgray ultraviolet rays for 15 minutes.

\section{Experimental Design}

Completely randomized factorial experimental design with two replications was applied in this study. Factors investigated were irradiation treatment and moulding period. Prior to moulding process, dried fish sticks were divided into two lots, i.e. with and without irradiation treatments. Moulding periods observed were $1,2,3$, and 4 weeks.

\section{Analyses}

Analyses and observation to the dried fish stick during moulding process were carried out every week. Chemical analyses including $\mathrm{pH}$ using 766 Calimatic pH m (Anonymous, 1979); phenol content (DG of Fisheries, 1981); protein content (Anonymous, 1979); fat content (Anonymous, 1979); moisture content (Anonymous, 1979). Mould growth was observed visually. Organoleptic analyses were performed by 15 panellists to assess the acceptability of the product using 9 hedonic scale, especially in terms of taste and odour. To prepare samples for organoleptic testing, the dried fish stick was planed down completely using a wood plane and then put into $150 \mathrm{ml}$ water. The mixture was boiled for 10 minutes and filtered to obtain fish extract. The extracts were ready to be served to panellists.

The data were analyzed by analysis of variance (Anova) to determine differences among the treatments. When F-values significant, honestly differences were determined. Kruskal-Wallis test was used to analyze organoleptic data.

\section{RESULTS AND DISCUSSION}

\section{Chemical Changes in Dried Fish Stick During Preparation and Moulding}

Fat content of little tuna used as raw material of dried fish stick in this study was low and predicted not to create any problem during processing of the product. Boiling process induced reduction of both moisture and fat contents (Table 1). Heating or boiling brought about coagulation and denaturation of fish protein to facilitate the release of liquids from solids (Bimbo, 1990). It is known that when the fish flesh is heated, a significant proportion of water is released from the protein. This process might have encouraged the reduction of both moisture and fat contents of fish due to boiling as demonstrated in the processing of dried fish stick. 
Sharp reduction of moisture content in fish was found due to smoking treatment as final step to produce dried fish stick product. Smoking conducted several times at 60 to $80^{\circ} \mathrm{C}$ was aimed to obtain gradual release of water from the fish till constant weight achieved. Therefore, this process was able to result in a product with very low moisture content, i.e. $14.91 \%$. However, that moisture content level increased again after moulding process.

Table 1. Moisture, protein, and fat contents of little tuna through the process of dried fish stick

\begin{tabular}{lcccc}
\hline \multicolumn{1}{c}{ Analyses } & $\begin{array}{c}\text { Fresh little tuna } \\
\text { prior to boiling }\end{array}$ & After boiling & After smoking & After moulding \\
\hline Moisture content (\%) & 76.3 & 66.74 & 14.91 & 22.76 \\
Protein content (\%) & 21.2 & 35.46 & 80.25 & 73.50 \\
Fat content (\%) & 2.1 & 1.51 & 4.2 & 3.37 \\
\hline
\end{tabular}

During moulding process, moisture contents of both irradiated and not irradiated dried fish sticks increased. The moisture increase was probably mainly due to that the product was in order to achieve equilibrium with surrounding condition. Dried fish stick obtained from smoking process had very low moisture content, i.e. 8.39 and 8.41 for irradiated and not irradiated products respectively. The relative humidity in the glass boxes used for moulding process was kept in the range of 85 to $95 \%$. Those relative humidity levels bought the moisture contents of the products to increase gradually in the second, third and fourth weeks moulding period (Table 2). That condition also showed its' impact to water activity $\left(a_{w}\right)$ values of the product, in which $\mathrm{a}_{\mathrm{w}}$ values tended to increase through moulding process, i.e. from 0.79 to 0.90 and from 0.78 to 0.88 for irradiated and not irradiated samples correspondingly. The $a_{w}$ values are an important factors affecting microorganism growth and sometimes showing positive correlation with moisture content. Winarno (1980) described that microorganisms will not grow without water, and water demand for microorganisms growth is referred as water activity $\left(a_{w}\right)$. Moulds grow well in the environment at $a_{w}$ level of 0.80 to 0.90 (Buckle et al., 1987). Minimum $a_{w}$ requirement for $A$. repens is 0.71 (Hultin \& Milner, 1970). The $a_{w}$ value range of dried fish stick during moulding process in this study was actually suitable for mould growth including for $A$. repens.

$\mathrm{pH}$ values of dried fish stick showed a trend to increase during moulding process. Those increases might be due to the decomposition of protein by microorganism and enzymes into simple substances, e.g. nitrogen and others. Volatile bases produced during that decomposition process, such as ammonia, simple methylamine, di methylamine, and tri methylamine, probably also contributed in the increase of $\mathrm{pH}$ values of dried fish stick during moulding process.

Table 2. Chemical changes in dried fish stick through moulding process

\begin{tabular}{cccccc}
\hline $\begin{array}{c}\text { Irradiation } \\
\text { treatment }\end{array}$ & $\begin{array}{c}\text { Moulding periods } \\
\text { (weeks) }\end{array}$ & $\begin{array}{c}\text { Moisture } \\
\text { content }(\%)\end{array}$ & $\mathrm{pH}$ & $\mathrm{a}_{\mathrm{w}}$ & $\begin{array}{c}\text { Phenol content } \\
(\mathrm{mg} / \mathrm{g})\end{array}$ \\
\hline Irradiated & 1 & $8.39 \mathrm{a}$ & $5.91 \mathrm{a}$ & $0.79 \mathrm{a}$ & $3.32 \mathrm{a}$ \\
& 2 & $12.09 \mathrm{a}$ & $6.43 \mathrm{bd}$ & $0.83 \mathrm{abd}$ & $0.20 \mathrm{~b}$ \\
& 3 & $19.46 \mathrm{~b}$ & $7.05 \mathrm{~cd}$ & $0.87 \mathrm{bc}$ & $0.64 \mathrm{~b}$ \\
Not irradiated & 4 & $24.08 \mathrm{~b}$ & $6.85 \mathrm{~cd}$ & $0.90 \mathrm{c}$ & $0.65 \mathrm{~b}$ \\
& 1 & $8.41 \mathrm{a}$ & $5.94 \mathrm{a}$ & $0.78 \mathrm{a}$ & $2.60 \mathrm{a}$ \\
& 2 & $12.71 \mathrm{a}$ & $6.30 \mathrm{~b}$ & $0.82 \mathrm{abd}$ & $0.57 \mathrm{~b}$ \\
& 3 & $19.19 \mathrm{~b}$ & $6.61 \mathrm{bd}$ & $0.89 \mathrm{c}$ & $0.40 \mathrm{~b}$ \\
\end{tabular}

Phenol content of dried fish stick tended to decrease due to moulding process. According to Sumartini (1993) phenol compounds are grouped in alcoholic compounds which are easily to evaporate. Phenol compounds which are very volatile are guaiacol and its homolog compounds. Cutting (1965) informed that phenol compounds are susceptible to light and oxygen. Sharp decrease of phenol content occurred in the second week of moulding process. Further moulding process induced small changes of phenol content.

In terms of organoleptic acceptability, dried fish stick processed without irradiation treatment showed better taste and odour acceptability compared to the one with irradiation treatment (Table 3). It was guessed 
that probably more mould species grew in the dried fish stick without irradiation treatment bringing about more compounds generating taste and odour of the product. That fact resulted in panellists gave higher taste and odour scores to the product without irradiation treatment. $A$. repens was suspected to dominate moulds growing on the surface of irradiated dried fish stick. Flavour of dried fish stick which has undergone moulding process is formed by volatile and non-volatile compounds. Volatile compounds are such as products from degradation and O-methylation processes of phenol produced during smoking (Doi et al., 1989). Non volatile compounds are such as amino acids, nucleotides, and organic acids (Sakakibara et al., 1990).

Table 3.

Organoleptic changes in dried fish stick through moulding process

\begin{tabular}{|c|c|c|c|}
\hline Irradiation treatment & Moulding periods (weeks) & Taste & Odour \\
\hline \multirow[t]{4}{*}{ Irradiated } & 1 & 5.2 & 3.8 \\
\hline & 2 & 4.7 & 4.0 \\
\hline & 3 & 5.4 & 3.2 \\
\hline & 4 & 5.3 & 5.5 \\
\hline \multirow[t]{4}{*}{ Not irradiated } & 1 & 5.3 & 5.5 \\
\hline & 2 & 6.0 & 4.8 \\
\hline & 3 & 5.3 & 3.6 \\
\hline & 4 & 5.5 & 5.5 \\
\hline
\end{tabular}

In the beginning of moulding process, moulds grew as white spots on the surfaces of both dried fish stick with and without irradiation treatments (Table 4). Moulds grew extensively in the second week and this occurrence made the surface of the dried fish stick covered by white colour moulds. The mould growth in the third week was the same as found in the second week, but the colour of mould turned into greenish yellow. However, the mould growth reduced in the fourth week of moulding, in which some spots without mould growth were found on the surface of the dried fish stick. At that period, moisture and $a_{w}$ of the product were 21.44 to $24.08 \%$ and 0.88 to 0.90 respectively. Those values were probably inappropriate for the growth of mould

Table 4. Visual observation of mould growth development in dried fish stick during moulding process

\begin{tabular}{cl}
\hline Moulding period & \multicolumn{1}{c}{ Visual mould growth development } \\
\hline $1^{\text {st }}$ week & moulds grew as white spots on the surface of dried fish stick \\
$2^{\text {nd }}$ week & moulds grew enormously making the surface of dried fish stick white like covered by cotton \\
$3^{\text {th }}$ week & moulds covered the surface of dried fish stick, but the colour changed to greenish yellow \\
$4^{\text {th }}$ week & growth rate of mould reduced inducing some spots without moulds \\
\hline
\end{tabular}

\section{CONCLUSION}

Moulding process in the production of dried fish stick Katsuobushi should not be conducted more than 3 to 4 weeks. Irradiation was not recommended to apply prior to moulding process of dried fish stick, since reduced organoleptic acceptability of the product.

\section{ACKNOWLEDGEMENTS}

I would like to thank Mr. Suyuti Nasran who have contributed his expertise for the success of the experiment. This study was funded by Slipi Research Station for Marine Fisheries (fiscal year of 1997/1998) under title Development of Fermentation Technique for Dried Smoked Fish Stick (Katsuobushi).

\section{REFFERENCES}

Anonymous. 1979. Methods and procedures of chemical analyses for fishery products. Lembaga Teknologi Perikanan. Jakarta. (Indonesian).

Basmal, J. \& H. E. Irianto. 2000. Added value improvement of dried fish stick through moulding process. Warta Penelitian dan Pengembangan Pertanian. 22 (1). 7-9. (Indonesian). 
Bimbo, A. P. 1990. Production of fish oil. In Fish Oil. In Nutrition. M. E. Stansby (ed). 141-180. Van Nostrand Reinhold. New York.

Buckle, K. A., R. A. Edward, G.H. Fleet, \& M. Wootton. 1987. Food science. Translated into Indonesia by H. Purnomo \& Adiono. University of Indonesia. Jakarta.

Cutting, C. I. 1965. Smoking. In Fish as Food. Vol.III. G. Borgstrom (ed). Academic Press. New York.

D. G. Fisheries. 1981. Compilation of practical guide for chemical analyses of fishery products. D. G. Fisheries. Jakarta. (Indonesian).

Doi, M., M. Ninomiya, \& M. Matsui. 1989. Degradation and O-Methylation of phenols among volatile flavour components of dried bonito (Katsuobushi) by Aspergillus species. Agricultural Biology Chemical. 53 (4). 1051-1055.

Hultin, H. O. \& M. Milner. 1970. Post-harvest biology and biotechnology food and nutrition. AVI Press Inc. West Port. Connecticut.
Onions, A. H. S., D. Allsopp, \& H. O. W. Eggins. 1981. Smith's introduction to industrial mycology $7^{\text {th }}$ edition. Edward Arnold Publ. Ltd. London.

Sakakibara, H., M. Hosokawa, I. Yajima, \& K. Hayashi K. 1990. Flavour constituens of dried bonito (Katsuobushi). Food Reviews International. 6 (4). 553-572.

Sumartini, L. C. 1993. Effects of smoke source and smoking period on the quality of smoked yellow fin tuna (Thunnus albacores) during storage. S1 Thesis. Faculty of Fisheries. Bogor Agricultural University. Bogor. (Indonesian).

Tanikawa, E. 1971. Marine products in Japan. Kosiesha-Koseikaku Co. Tokyo.

Winarno, F. G. 1980. Introduction to food technology. PT. Gramedia. Jakarta. (Indonesia). 
